\title{
The COVID-19 Pandemic, International Cooperation, and Populism
}

\author{
Jon C.W. Pevehouse (ㅇ)
}

\begin{abstract}
Inconsistent efforts at international cooperation often undermined global efforts to mitigate the COVID-19 health pandemic. Pundits and scholars alike laid much of the blame for this lack of cooperation on domestic political factors, especially populist leaders. Could international relations theories have predicted this behavior? I argue that there are no off-the-shelf theories that engage populism with traditional mechanisms of international cooperation, especially cooperation facilitated by international institutions. I explore how populist sentiment, whether stemming from the public or leaders, can pose barriers to cooperation. I argue that populists are especially likely to resist cues from foreign actors; are especially reticent to delegate national sovereignty; and are especially resistant to policies that result in gains for elites and, when coupled with nationalism, foreigners. The essay concludes with suggestions for further theoretical and empirical research.
\end{abstract}

As a global health pandemic, the COVID-19 crisis required significant international cooperation to blunt its magnitude and its effects. Unfortunately, at least through the end of 2020 only limited international cooperation had emerged. While some countries supported global efforts through the World Health Organization (WHO), others, such as the United States, mostly criticized the organization's efforts. And even nonAmerican leaders in Europe were skeptical that countries that were supposedly cooperating-China, for example-were actually living up to their promises. ${ }^{1} \mathrm{~A}$ global crisis that needed coordination and cooperation was instead characterized by defection and dissension. ${ }^{2}$

Domestic political forces have been proffered as a possible explanation for some countries' resistance to international cooperation in the face of the pandemic. Specifically, observers have pointed fingers at the populist and nationalist-populist movements that have gained significant support across a range of countries in

Editor's note: This article is part of an online supplemental issue on COVID-19 and international relations. The authors were invited by $I O$ 's editorial team and guest editor Michael C. Horowitz. The manuscript was reviewed based on written non-anonymous reviewer comments and during an online workshop. The revised manuscript was evaluated by the $I O$ editorial team. We appreciate the support of Perry World House at the University of Pennsylvania for making this possible.

1. "China delayed releasing coronavirus info, frustrating WHO," Associated Press, June 3, 2020.

2. These international disparities parallel the variation in countries' domestic responses, which ranged from shutting down quickly and completely (e.g., South Korea) to practically denying the existence of any problem (e.g., Brazil) to a hodgepodge of poorly-coordinated local policies (the U.S.). The diversity of domestic responses only increased as the infection curve flattened and debates emerged about when to re-opening economically and when to relax social distancing rules. 
recent years. Countries that are home to these movements seemed on average less likely to support international efforts.

Can existing international relations (IR) theories explain the patterns of international cooperation that we observed in 2020 ? In this essay, I argue that while we have a wide range of theories of domestic politics and international cooperation ${ }^{3}$ there are no off-the-shelf theories that explain how populist movements may influence international cooperation. This is an important exercise both in allowing IR to speak to the current historical moment and also in reconciling existing findings on the laudatory effects of international organizations (IOs) in creating public support for cooperation ${ }^{4}$ with the contrary narrative of a backlash against global cooperation arrangements.

Existing theories do provide a starting point. I focus on three domestic factors that scholars have argued are especially important for explaining countries' willingness to cooperate internationally: receptivity to informational cues from international actors, willingness to give up national sovereignty by delegating power to international institutions, and concerns about the distribution of gains from cooperation (both domestically and internationally). For each one, I explain how populist sentiment-whether stemming from the public or leaders-can pose barriers to cooperation. In short, I argue that populists are especially likely to resist cues from foreign actors; are especially reticent to delegate national sovereignty; and are especially resistant to policies that result in gains for elites and, when coupled with nationalism, foreigners. Thus, populist ideology can pose formidable barriers to international cooperation.

In the pages that follow, I begin by briefly justifying my focus on domestic factors such as mass public attitudes and the attitudes of national leaders. I then propose a series of hypotheses about the possible effects of populist leaders and movements on international cooperation. Finally, I note that the causal arrow can go in both directions, and advocate for more research investigating how international factors have shaped nationalist-populist movements, especially outside of Europe. ${ }^{5}$

Of the work in this online supplement, this essay falls squarely in the "inspired by COVID" camp. COVID-19 has stimulated significant commentary about how various domestic and international factors influence and are influenced by the global pandemic. ${ }^{6}$ Core among these dynamics is the realization that populism, and nationalist-inspired populism specifically, has become enmeshed with the pandemic. ${ }^{7}$

A New York Times article on the pandemic noted a common narrative: "Where the

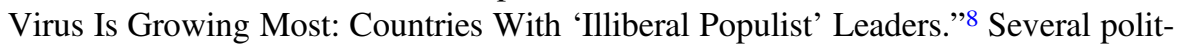
ical scientists are cited as suggesting that countries with nationalist-populist leaders

3. For example, Fang 2008; Mattes and Rodriguez 2014.

4. For example, Thompson 2006; Putnam and Shapiro 2017.

5. For an exception, see Verbeek and Zaslove 2017.

6. See Drezner 2020 for an overview.

7. See Linsker 2020; Rachman 2020.

8. David Leonhardt and Lauren Leatherby, "Where the Virus Is Growing Most: Countries With 'Illiberal Populist' Leaders,” New York Times, June 2, 2020. 
(specifically "illiberal populists") are seeing the virus run rampant; the four states with the highest infection rates (the US, the UK, Brazil, and Russia) were all governed by populist leaders. The mechanisms suggested for this observation included a rejection of international cooperation and a rejection of expertise advising more stringent government responses.

We have little off-the-shelf theory (other than broad ideas that "domestic politics matter") suggesting specific mechanisms to explain why populist-nationalist movements should reduce international cooperation or policy coordination. However, there are many places to look for insight about how domestic political movements can translate into international behavior: theories about how interest groups, ${ }^{9}$ coalitions,${ }^{10}$ compliance constituencies,${ }^{11}$ and veto players ${ }^{12}$ shape international cooperation could all offer insight. Moreover, a sizable and growing body of empirical and experimental work suggests that mass publics can shape cooperation and governance in both positive and negative ways in areas such as human rights, ${ }^{13}$ international law, ${ }^{14}$ trade, ${ }^{15}$ supranationalism, ${ }^{16}$ and compliance with international courts. ${ }^{17}$ Is it possible to incorporate populist nationalism into these existing works, and if so, how?

\section{Defining Populism}

To begin, it is worth reviewing the concepts of populism and nationalism. Most scholars adopt a definition of populism offered by Mudde and Kaltwasser as a "thin-centered ideology that considers society to be ultimately separated into two homogenous and antagonistic groups, 'the pure people' versus 'the corrupt elite' and that politics should be an expression of the general will of the people." 18 A key part of this definition is the "thin-centered" concept that there are no ideologically-driven policy preferences that necessarily flow from populism. According to Mudde and others, these preferences are attached to particular populist movements by leaders who claim to represent "the people."19 This definition thus helps explain why one can find significant heterogeneity among populist movements in terms of their place on the traditional left-right spectrum and their views towards international organizations and cooperation. ${ }^{20}$

9. Grossman and Helpman 2002.

10. Snyder 1991.

11. Dai 2005; Simmons 2009.

12. Mansfield, Milner, and Pevehouse 2007.

13. Putnam and Shapiro 2017.

14. Kreps and Wallace 2016.

15. Chaudoin 2014.

16. Hobolt 2016; de Vries 2018.

17. Voeten 2013; Madsen et al, 2020.

18. Mudde and Kaltwasser 2013.

19. Mudde 2014.

20. Verbeek and Zaslove 2017; Copelovitch and Pevehouse 2019. 
Yet despite the lack of a core ideological set of beliefs to generate policy prescriptions (contra Marxism, for example), deducing a set of preferences from populists regarding international cooperation preferences is a straightforward and potentially valuable exercise. By definition, populist leaders and populist-oriented publics will be anti-elite at their core. Given the common perception that foreign affairs and internationalism are elite interests, we should not be surprised to find that populist movements are often skeptical of international engagement. For example, in the United States there is a long history of the general public viewing domestic institutions such as the State Department through the prism of elitism, which some scholars argue was historically well-deserved. ${ }^{21}$

Given the association of many multilateral cooperation institutions with elites and elitism, populists of most stripes are skeptical of international and regional governance institutions. ${ }^{22}$ Global institutions are often described as distant and technocratic, ${ }^{23}$ anti-democratic, ${ }^{24}$ and elitist. ${ }^{25}$

A close kin to anti-elitist views are anti-expert views. The COVID-19 crisis has driven home this facet of populism quite clearly. Populist leaders (and their followers) have routinely denounced expert communities (what in IR we would label epistemic communities). ${ }^{26}$ Given that these epistemic communities of scientists and medical professionals often operate and network across borders, it is fairly easy to see them as part of the elite whether the issue is global health or climate change. ${ }^{27}$

Beyond anti-elitism, the literature suggests there are few other strong belief structures common to populist movements. ${ }^{28}$ Populist movements can pick up additional beliefs to meld with anti-elitism. One common belief that seems to go hand-in-hand with current populist movements is nationalism.

Nationalism can be a natural outgrowth of populism if a leader's or movement's definition of "the people" stops at national borders. This is why nationalism is often a handmaiden to populism: defining "the people" along geographic boundaries is quite easy for politicians. However, as Copelovitch and Pevehouse have argued, this need not be the case. ${ }^{29}$ Indeed, the populists of Latin America in the 1970s defined their calls against elites as a movement against the Western-supported neoliberal system. ${ }^{30}$ In this view, nationalism is a variable that may or may not be present in populist movements. ${ }^{31}$ Still, the very presence (and ubiquity) of the phrase "nationalist-populism" suggests a relationship between the two.

\author{
21. Hook 2003. \\ 22. Verbeek and Zaslove 2017, 21. \\ 23. Rubenfeld 2004. \\ 24. Dahl 1999. \\ 25. Rabkin 2005. \\ 26. Haas 1992. \\ 27. See Johnson's 2020 essay on this idea. \\ 28. Mudde and Kaltwasser 2013. \\ 29. Copelovitch and Pevehouse 2019. \\ 30. Johnson 1983. \\ 31. See also Verbeek and Zaslove 2017.
}


Still, although populist leaders may further divide the "true people" domestically, the social identity politics of defining those outside one's borders as not part of the ingroup is a tried and true strategy. ${ }^{32}$ Populist leaders often attempt to mobilize opinion around issues such as cross-border immigration, trade, and the threat of terrorism. For now, however, note that this argument requires that citizens can be mobilized around traditional foreign policy issues: an assumption we cannot take for granted.

The remainder of this essay evaluates how the core of anti-elitist beliefs, sometimes coupled with a companion belief of exclusive nationalism, intersects with our existing theories and knowledge about international cooperation. In each case, I show how populist (or in some cases nationalist-populist) beliefs link to existing theories of cooperation to suggest the mechanism linking that ideology to international cooperation (or the lack thereof). First, however, I review a more fundamental question concerning public attitudes and international relations: does the public matter at all?

\section{The Domestic Politics of International Cooperation}

Any attempt to theorize about how the populist trends in domestic politics influence international cooperation seems to presume that public opinion and leaders matter for foreign policy. It is worth noting that there is work suggesting that the public does not actually care about foreign policy. ${ }^{33}$ Similarly, some scholars suggest public opinion plays little role in the formulation of policy. ${ }^{34}$

Yet the common narrative of the rise of populism and anti-globalization backlash is that a portion of the public has turned against globalization and its attendant institutions. These two positions are in tension. If publics are unlikely to care about these issues, let alone vote on them, it is doubtful that leaders would address them so frequently. ${ }^{35}$

Leaders do address international cooperative arrangements, in part, because the know-nothing view of the public has been widely debunked in many studies. ${ }^{36}$ While the public may not excel at current events quizzes, that does not imply a lack of interest or consistent attitudes about foreign affairs. There is evidence in the area of international institutions that the public attempts to become more knowledgeable when events suggest those institutions are relevant. ${ }^{37}$

Similar work in foreign policy analysis suggests that the public has well-structured attitudes about multilateralism. The work attempts to isolate the dimensions over which groups of voters vary on their views of international affairs. Of particular relevance is work suggesting that, along with an isolationism-internationalism

32. This obviously requires a coherent national identity to be constructed. This would suggest nationalist-tinged populist movements should be rare in relatively new states.

33. Almond 1950. One could also consult Converse 1964. On this formulation, see Holsti 1992.

34. See Busby and Monten 2012; Page and Bouton 2006.

35. For contrary evidence on voting, see Colantone and Stanig 2018.

36. For example Holsti 1992; Baum and Potter 2008.

37. Pelc 2013; Voeten 2013. 
and militarism-non-militarism dimensions, a third multilateral-unilateral dimension is present in the structure of public attitudes towards international relations. ${ }^{38}$ This research suggests that questions of the structure of global governance are on an attitudinal dimension of their own, not comingled with questions of use of force or isolationism more generally.

When discussing domestic politics and international cooperation, especially in the context of populism, the question of leaders is also relevant. Specifically, are publics simply responding to elite cues? Long-running debates in American politics argue over who is leading whom, especially on the topic of international affairs. ${ }^{39}$

A recent investigation into these debates is the work of Guisinger and Saunders. ${ }^{40}$ They argue that leaders are relevant for public opinion and that there is still debate about whether elites move public views because of information or partisan cues. ${ }^{41}$ They further note it is possible that the mechanism could differ across issue area. And indeed, their own findings suggest this is the case: in some issue areas (environmental agreements), cues are largely followed on partisan lines; while in others (the World Trade Organization), cues are followed in a less partisan nature. Their theory suggests this is a function of the pre-existing polarization of the issue.

This strand of research is important given that there is strong evidence that masses pay more attention to issues when there is elite dissensus. ${ }^{42}$ Elite disagreement on policy issues is a cue to the media to relay these debates to the mass public, leading them to pay more attention to the issue. Thus, stark debates between traditional supporters of international institutions and those against them are likely to raise the salience of international issues in the eyes of the public. Aldrich, Sullivan, and Borgida show that as salience increases, voters are more likely to rank international issues as important to their votes. ${ }^{43}$

In addition, we know that leaders do engage their publics concerning international cooperation. Schmidtke reviews several years of elite rhetoric about three governance institutions (the G-8, European Union, and United Nations) from four countries. ${ }^{44}$ Although this work does not attempt to evaluate the influence of rhetoric on public views of the organizations, it finds no increase over time that suggests a secular rise in anti-IO rhetoric among elites. Their study should give rise to more investigations of how elites frame global governance issues to their publics, an issue I return to in the conclusion. Their finding of a strongly negative balance of elite statements is consistent with indexing theory: only when elites criticize and debate a policy issue does the media turn its lens to that issue. Thus, we should

38. Chittick, Billingsley, and Travis 1995. They revised the Wittkopf-Holsti-Rosenau two-dimension model.

39. Zaller 1992; Aldrich, Sullivan, and Borgida 1989; Page and Bouton 2006.

40. Guisinger and Saunders 2017.

41. On information, see Hiscox 2006. On partisan cues, see Berinsky 2009.

42. Bennett 1990; Soroka 2003. For an international relations example, see Howell and Pevehouse 2007.

43. Aldrich, Sullivan, and Borgida 1989.

44. Schmidtke 2019. 
probably not conclude that elites are generally unsupportive of international institutions given this data, but rather that the media highlights elite disagreements more than agreements.

The flip side of the "elites lead" coin is the possibility that leaders are constrained by public opinion. Tomz, Weeks, and Yarhi-Milo suggest that elites do take public views into account, at least in the area of security policy. ${ }^{45} \mathrm{~A}$ common approach in public opinion work suggests constraining effects, such as the anticipatory influence of public opinion. ${ }^{46}$ By this logic, leaders and elites may not directly read public mood on foreign policy issues, yet they have a sense of important boundaries set by the public, which serves as guide rails to policy choice.

Despite these important studies, we need far more evidence about the circumstances under which leaders lead or follow with regard to international affairs. Much of the current debate concerning the populist backlash to globalization and global governance centers on whether the populist leaders are cause or effect (or both). But as the COVID-19 crisis shows, both top-down and bottom-up backlashes against government responses are present, varying by country and over time within country. Assessing who led whom in particular episodes may be empirically difficult.

The next section thus takes for granted that populist leaders, their followers, and mass publics in general are relevant for the study of international cooperation, and develops hypotheses about how populist ideology, with its anti-elite foundations (and sometimes nationalist kin), can influence international cooperation

\section{Populist Ideology and International Cooperation}

Scholars of international cooperation have focused on a variety of ways in which domestic political actors are implicated in the prospects of international cooperation. The populist anti-elite views among populist leaders and a populace may influence international cooperation through multiple mechanisms: by undermining information effects of international institutions, hindering delegation, and resistance to the distribution of gains from cooperation. I discuss each of these mechanisms in turn.

\section{Receptivity to Information and Cues}

There are many theories of how international organizations facilitate cooperation through domestic politics via an information mechanism. The mechanism has been especially prominent in explanations of how international organizations interact with domestic political constraints. ${ }^{47}$ For example, early empirical work argued that mass publics responded favorably to what could be labeled endorsements by international organizations. For example, Chapman finds that UN Security

45. Tomz, Weeks, and Yarhi-Milo 2020.

46. Powlick and Katz 1998; Baum and Potter 2008.

47. Fang 2008. 
Council approval leads to increases in US presidential popularity surrounding the onset of military disputes. ${ }^{48}$ Thompson suggests that signals from international bodies can be informative to both leaders and publics regarding the use of force. ${ }^{49}$ Using an experimental design, Grieco and colleagues show similar endorsement effects among the American public from international institutions. ${ }^{50} \mathrm{Johns}$ and Davies find similar effects for the British public. ${ }^{51}$

Other recent empirical studies have examined the informational effects of international institutions on public attitudes outside the security realm, mostly in the area of international law. The typical experimental design informs respondents as to whether a behavior is consistent or inconsistent with existing law. Chilton examines the laws of war on public support for conflict..$^{52}$ Chilton and Versteeg and Wallace examine questions regarding international law and torture. ${ }^{53}$ Findley, Nielson, and Sharman explore anti-corruption laws. ${ }^{54}$ Chilton as well as Putnam and Shapiro investigate the influence of international law on support for human rights. ${ }^{55}$

The existing studies suggest that at least some portion of the public must value the information provided by cooperative institutions to shift opinion on policy preferences. Yet the anti-elite views inherent in populism should attenuate these effects. Given that institutions are elitist and operating for the benefit of a privileged class, information from them is likely to be less credible. We should expect individuals with populist-oriented beliefs to be less moved by information from and endorsement by international institutions. Note the mechanism: completely discounting the information no matter whether it is favorable or unfavorable to the interests of the state. Populists should dismiss the information as inherently biased against "the people," since it arises from an elite institution, regardless of whether or not the institution is representative of their interests. ${ }^{56}$ Thus, these anti-elite views (which also beget anti-expertise views) should lead to a complete populist discounting of all information from elite institutions (domestic and international) regardless of an institution's perceived alignment with populist goals. I return to whether perceived preference similarity may negate this dynamic below.

What other information-related mechanisms may be influenced by the anti-elitism of populist movements? Another possibility is the compliance-inducing effects of naming and shaming. ${ }^{57}$ Because populists will heavily discount or completely ignore information from elitist international organizations, news that their own country's policies are not in line with expectations of other member states will be unlikely

48. Chapman 2009.

49. Thompson 2006.

50. Grieco et al, 2011.

51. Johns and Davies 2014.

52. Chilton 2015.

53. Chilton and Versteeg 2016; Wallace 2013.

54. Findley, Nielson, and Sharman 2013.

55. Chilton 2014; Putnam and Shapiro 2017.

56. For example, Thompson 2006.

57. Keck and Sikkink 1998; Hafner-Burton 2008. 
to ruffle a populist's feathers, let alone encourage policy change. One could even imagine such condemnation as a badge of honor for the unapologetic populist.

A related mechanism through which populism may attenuate naming and shaming involves a political psychology-oriented explanation that works through leaders. Some scholars of populism have linked its presence to a cult of personality around its leaders. Psychological assessments of world leaders tend to find a high degree of narcissism in those who are populists. ${ }^{58}$ It is also well understood in psychology that narcissism and shame do not mix. ${ }^{59}$ If naming and shaming depends on a leader feeling shame before instigating policy change, it will be a long wait for that change.

Both the information and the psychological mechanism predict that populism is likely to lessen cooperation that might have happened due to naming and shaming. For example, Tingley and Tomz's findings, based on their multi-country survey on the role of reciprocity in public attitudes on climate change, suggest that shaming in international fora can encourage cooperation. ${ }^{60}$ They contend that international agreements would garner more public support by incorporating these ideas into their design. Yet naming and shaming may be less helpful in populist-led or populist-majority countries.

\section{Delegation}

A second factor supporting international cooperation is states' willingness to delegate to international organizations. When states delegate, they inevitably encounter some level of sovereignty costs, defined as the legal surrendering of policy discretion to international organizations. ${ }^{61}$ Sovereignty costs are generally conceived of as a design issue: all international institutions are meant to restrict the policies of member states in some way, though the level of sovereignty costs varies across agreements. ${ }^{62}$ The key point is that without some tolerance of sovereignty costs, international cooperation becomes impossible.

Delegation also brings the conveyance of political authority, which shapes the legitimacy of international institutions. It is also argued that without legitimacy international organizations are unlikely to achieve their goals. ${ }^{63}$ Unfortunately, populists would seem to be especially sensitive to any loss of national sovereignty. In general, outsiders' interruption of governance by the "pure" people is unthinkable for the populist, who should therefore tend to eschew delegation to international organizations. For populists, "the people" certainly do not include bureaucrats from international organizations. Populists will be unwilling to suffer the sovereignty costs imposed by delegation to international institutions and should also find this

58. Nai and Martinez i Coma 2019.

59. Zaslov 1998.

60. Tingley and Tomz 2014.

61. Moravscik 2000.

62. Hafner-Burton, Mansfield, and Pevehouse 2015.

63. Tallberg, Bäckstrand, and Scholte 2018. 
delegation of authority a source of illegitimacy of international organizations. I examine the sovereignty cost and legitimacy mechanisms in turn.

Particularly relevant for international cooperation has been work discussing sovereignty costs in the area of human rights institutions. Not surprisingly, populist-nationalist movements have been particularly reticent to cooperate with international human rights institutions, and present a challenge to them. ${ }^{64}$ Whether that challenge is attempting to roll back delegation to those institutions (e.g., withdrawal) or arguing they are promoting a different conception of human rights altogether (e.g., religious rights), populists do not have a strong track record of accepting sovereignty costs from international human rights institutions.

But concerns about delegation are not only relevant for human rights. In existing scholarship it is not difficult to find examples of fear of delegation to international organizations among the public in other issue areas. For example, recent work by Hahm and colleagues on the Transatlantic Trade and Investment Partnership (TTIP) agreement suggests that surrendering dispute settlement to third party arbitration is particularly unpopular among the public. ${ }^{65}$ Their findings held across a number of individual-level characteristics.

Similarly, Milner and Tingley find in a survey of Americans that support for the multilateral (versus bilateral) provision of foreign aid is relatively low. ${ }^{66}$ They suggest their findings are consistent with the principal-agent model: citizens are hesitant to delegate foreign aid dollars to organizations which do not align closely with their preferences. Their findings are especially strong for self-identified conservatives who feel international institutions do not reflect their preferences. ${ }^{67}$

Neither of these studies assess populism as a source of anti-delegation attitudes. Yet both studies raise an important question: is it delegation per se (e.g., reduced policy flexibility) that populists may reject or is it conditional on the expected preferences of the agent (the classic delegation dilemma of the principal-agent model)? Or are populists more sensitive to small divergence of preferences given more extensive delegation? Does agreement flexibility ${ }^{68}$ assuage populists?

From a purely populist ideological perspective the answer could be that delegation in and of itself is a betrayal of a legitimate governance process run by "the people." Because those who would be delegated authority are not part of the pure people, populists should also see governance processes within international institutions as dangerous. The classic refrain of "who elected the bureaucrats" should ring loudly.

Recent empirical work, however, suggests that theoretical concerns over delegation could be less of a concern than is generally supposed. Madsen and colleagues conduct a survey experiment in five European countries to determine if objections to supranational courts are based more on procedural (overruling national courts) 
or substantive (disagree with decisions) grounds. ${ }^{69}$ They find that respondents are more likely to object to the substance of a decision versus a violation of sovereignty. In other words, respondents were more likely to accept a European court ruling if they agreed with an outcome, even if it overruled their own domestic court.

Empirical findings in the issue area of climate change are also relevant. Bechtel and Scheve find public support for international climate agreements tied to issues of institutional design. ${ }^{70}$ Through a series of survey experiments in four countries, they show that issues of enforcement, participation, and cost and distribution play an important role in shaping public support for a hypothetical climate agreement. Their findings speak to questions of public support for particular notions of delegation and its importance for regime design.

In this discussion both preferences and legitimacy loom large. Turning to the concept of legitimacy helps put the earlier question of preferences and delegation versus process into sharper relief. Populists are likely to see delegation to international institutions as an illegitimate delegation. For example, recall Boris Johnson's consistent suggestion that the EU "subverts our democracy."71 This is not an argument that the EU has different preferences, but that decisions in Brussels are not decisions made in London and are therefore problematic from a process perspective.

This line of argument dovetails nicely with recent research on the legitimacy of international institutions. Recent empirical work has responded to contestation over multilateralism ${ }^{72}$ with new survey work examining what shapes public perceptions of IO legitimacy. A common frame within this legitimacy research paradigm is whether the public is more concerned about the processes within an institution (process legitimacy) or the effectiveness of institutions (output legitimacy). Empirical findings, including survey experiments in four countries by Delmuth, Schulte, and Tallberg show that concerns about both are important to the public. ${ }^{73}$ They also show, however, that whether process or output is more important varies by issue area.

To assess the power of the populist ideology (especially as distinct from concern over preferences), more work is needed to uncover the origins of public views about legitimacy of international organizations. If support is simply a function of the perceived preference distance between an institution and an individual, this may leave little room for some of the thicker notions of legitimacy involving consultative or deliberative notions. Are the roots of concerns over delegation about normatively-based legitimacy issues? Or is the concern more materialist: sovereignty costs inherently involve delegation which limits a state's potential policy latitude

69. Madsen et al, 2020.

70. Bechtel and Scheve 2013.

71. Boris Johnson, "EU Exit a 'Win-Win' for us all," $B B C$ News, March 11, 2016, retrieved from $<$ https://www.bbc.com/news/uk-politics-eu-referendum-35783049>.

72. On this contestation, see Buchanan and Keohane 2006; Morse and Keohane 2014.

73. Delmuth, Schulte, and Tallberg 2019. 
and also brings the risk that international institutions could inflict policy outcomes far away from the country's ideal point. ${ }^{74}$

Finally, when considering the question of populism and the legitimacy of international institutions, it is important to note that a broader literature on legitimacy and international organizations originated not from a right-leaning populist perspective but a more critical, often left-leaning perspective. For example, O'Brien et al. explore contestations of global governance through global social movements. ${ }^{75}$ Nearly four decades ago, Johnson argued that the emergence of the New International Economic Order (NIEO), for example, was spurred on by a version of left-wing populism in the developing world. ${ }^{76}$ The contestation of multilateralism, to borrow Morse and Keohane's phrase, has arisen from both ends of the traditional left-right political spectrum. ${ }^{77}$

\section{The Distributional Effects of Cooperation}

A third factor that scholars have identified as influencing the prospects for international cooperation involves the domestic and international distribution of gains. If international institutions bring gains from cooperation, as argued by international relations theorists, ${ }^{78}$ leaders and their publics will be concerned about the distribution of those gains both domestically ${ }^{79}$ and internationally. ${ }^{80}$

First, consider the domestic gains from cooperation. It is easy to see how populism might heighten fears that the gains from international cooperation will accrue primarily to domestic political elites. Given that populists see international agreements as negotiated by elites, they assume elites will reap the benefits of these agreements.

One clear example of this populist-inspired concern over the benefits of cooperation is in the area of trade agreements. Populists have railed against trade agreements as benefitting only a select few within society. In sum, relative gains in a domestic context. Indeed, populists have seemingly been willing to sacrifice policy (trade liberalization) that could benefit them if it also sacrifices gains for elites. Milner, in her pathbreaking work, foreshadowed this idea (although without the populist-inspired context) and suggested these division-of-gains concerns could decrease the probability of cooperation. ${ }^{81}$ The past few years seem to have borne out her prediction in the area of trade policy.

This pattern appears to hold regardless of the political leanings of populists. Indeed, much of the left-leaning populist objection to trade agreements has focused

74. Tallberg and Zürn 2019 label these aspects of legitimacy "procedures and performance". The empirical works in their special issue begin to address the legitimization processes around international organizations including non-governmental organizations.

75. O'Brien et al. 2000 .

76. Johnson 1983.

77. Morse and Keohane 2014.

78. Keohane 1984.

79. Milner 1997.

80. Powell 1991.

81. Milner 1997. 
on their role in exacerbating inequality domestically. Bernie Sanders opposed the renegotiated North American Free Trade Agreement agreement-the United States Mexico-Canada Agreement-based on objections that it did too little to redistribute gains domestically to workers and family farms. ${ }^{82}$ But right-leaning populists will often adopt this rhetoric as well, as Donald Trump famously did throughout his campaigns and presidency. As he noted in 2016, "Our politicians have aggressively pursued a policy of globalization, moving our jobs, our wealth, and our factories to Mexico and overseas. Globalization has made the financial elite, who donate to politicians, very, very wealthy. I used to be one of them." 83

So far, I have focused on the implications of populist anti-elite ideology on concerns over the domestic division of gains from cooperation. But if populists also subscribe to an exclusive nationalist ideology, they will likely worry about the international distribution of gains from cooperation as well; here we can turn to the concept of relative gains.

Relative gains concerns should also loom large for the populist-nationalist. This has been a constant strand of rhetoric from nationalist leaders such as Donald Trump and Boris Johnson: international agreements that do not maximize their country's own payoff should be abandoned. Powell noted that under some conditions, relative gains concerns could impede cooperation. ${ }^{84}$ Specifically, when relative gains could more easily be turned into an advantage for one state, states will be more sensitive to those gains.

And although Powell's game theoretic model centered on military contests, it is not a stretch to notice this logic in the populist objection to international cooperation in security and economic areas. The Trump administration's threats to withdraw from the North Atlantic Treaty Organization (NATO) agreement due to what it saw as an unfair cost allocation was often rooted in the idea that NATO allies were using American largesse to challenge the US and help US competitors. ${ }^{85}$

One analytical question is whether a highly nationalist leader (without the populist ideology) would behave differently. In terms of relative gains concern, the answer is likely no: heightened concerns for relative gains and the ends to which those gains can be put are no doubt higher for all stripes of nationalists. Nationalists are more likely to see threats around them and thus have concerns about how relative gains may be used. ${ }^{86}$ Yet the populist-nationalist adds both a concern about the domestic distribution of those benefits and a concern about the legitimacy of an elite-led process divorced from a direct input from "the people."

82. "Sanders Opposes Trump's USMCA: Full Statement," January 15, 2020. Retrieved from <https:// www.sanders.senate.gov/newsroom/press-releases/sanders-opposes-trumps-usmca-full-statement>.

83. "Read Donald Trump's Speech on Trade," Time, June 28, 2016. Retrieved from <https://time.com/ 4386335/donald-trump-trade-speech-transcript/>.

84. Powell 1991.

85. Trump argued: "Germany is totally controlled by Russia ... We're supposed to protect Germany but they're getting their energy from Russia. Explain that." See "Trump Sets Combative Tone at NATO with Attacks on Allies." Retrieved from <https://www.pbs.org/newshour/show/trump-sets-combative-tone-atnato-with-attacks-on-allies>.

86. Powers 2020. 
As is evident from this brief analysis, there is important empirical yet theoretically scattered research linking domestic opinion and instruments of global governance. Before concluding with some suggestions for moving forward on this and other issues, I entertain an ever-present theoretical and empirical possibility: endogeneity.

\section{Does Cooperation Drive Nationalist-populism?}

I briefly address one final issue as we contemplate the role of publics on global governance in light of the rise of populism. In the spirit of Gourevitch, is there a possible second image-reversed ${ }^{87}$ element to populism? Verbeek and Zaslove argue that there is a distinct link between three international factors and the emergence of populism: the end of the cold war; the expansion of globalization; and the rise of regional governance institutions (particularly in Europe). ${ }^{88}$ The end of the cold war led to the expansion of democratic rule, giving populists an opportunity to come to power. Globalization has unleashed a number of processes that have challenged regional cooperation: less governmental control over the economy (especially in the developing world) ${ }^{89}$ new divisions cross-cutting traditional left-right political structures, ${ }^{90}$ and blurred geographic boundaries that lead individuals to search for new models of identity. ${ }^{91}$ Finally, an extensive literature on Euroskepticism has argued that regional institutions have fed the rise of populist backlash and led to even broader changes in the structure of public opinion..$^{92}$

This possibility raises obvious causal identification problems in future work on the interaction between public views on global governance institutions. In addition, at least two interesting possibilities arise when considering these outside-in possibilities. The first is the role of crisis (or "hard times") on public opinion. Ironically, some scholars have traditionally argued that external crises would be unifying events for mass publics. ${ }^{93}$ Yet the COVID-19 crisis did not bring particular unity or a rally effect. Rather, after a very brief time of seeming unity of publics and elites about both domestic and international policy responses, divisions quickly emerged. Many of these were of a partisan nature. This raises the possibility that current partisan lenses (especially in the United States) will condition how international crises shape public responses. ${ }^{94}$ Indeed, Myrick has argued that based on her recent experimental work, it is "unlikely that new threats will inherently create partisan unity." 95

87. Gourevitch 1978.

88. Verbeek and Zaslove 2017.

89. Rudra 2002.

90. Mutz 2018.

91. Verbeek and Zaslove 2017, 9.

92. Hooghe and Marks 2007.

93. Nincic 1992, 784.

94. Baum 2002.

95. Myrick 2020. 
Second, some work on regional governance had previously suggested that institutions could help processes such as democratization through mechanisms such as hand-tying ${ }^{96}$ or socialization. ${ }^{97}$ It appears that these processes may have also produced significant public backlash to those institutions, or at the very least, enterprising elites wishing to lessen the sovereignty costs of regional or international organizations have been effective at turning some segment of the public against these organizations. In this regard, the debates over the sources and consequences of democratic rollback ${ }^{98}$ should fully incorporate international and regional institutions' role in those processes. If elites are able to cast doubt on the hand-tying and socialization process of international organizations, their long-run effects on democratization and other domestic process should be questioned. ${ }^{99}$

In sum, concerns about endogeneity in this area are not trivial. Understanding how much of the public's attitudes about international governance institutions comes from individual traits and domestic contextual factors versus the influence of existing global institutions themselves-or elite framing of those institutions-will be an important set of questions to tackle in the next generation of scholarship.

\section{Where Do We Go From Here?}

The COVID-19 pandemic has further elevated questions and debates over populism and its effects in the field of international relations. I have argued that because populism is a thin ideology centered only on anti-elitism it is difficult to deduce clear expectations for its implications for international cooperation. Nonetheless, this anti-elitism ideology is relevant for some of our theoretical mechanisms in the study of cooperation. Specifically, I have argued that populism will attenuate the informational effects of international organizations, discourage the delegation of authority, and create concerns about relative gains domestically and internationally.

One important question to consider in closing: will populists or populist-nationalists cooperate at all? Given the anti-elitism and general disdain held by populists for elite-driven policy, it could be possible that populists might cooperate with other populists. In other words, only other "enlightened" leaders and publics are appropriate beneficiaries of cooperation. Work by Söderbaum, Spandler, and Pacciardi highlights that with regard to regional integration there is variation in levels of cooperation supported by populist leaders in Europe and Latin America. ${ }^{100}$

Copelovitch and Pevehouse have argued that populist leaders will still engage internationally, but this engagement will be mostly bilateral. ${ }^{101}$ The reason, 
consistent with the logic outlined above, is that smaller agreements can increase control while minimizing sovereignty costs and delegation. ${ }^{102}$

I have also raised a number of areas where further research could be helpful in evaluating these propositions and other dynamics related to general questions of public opinion and international cooperation. First, concerning populism specifically: populism rarely exists in a vacuum. Its thin ideology usually means it has an attendant set of beliefs such as nationalism. Indeed, most scholarly references to populismnationalist-populism, right-leaning populism, left-leaning populism-include adjectives. And while it is easy to recognize that other ideologies and beliefs are easily entangled with populism in practice, unentangling them for analytical purposes poses a challenge. For example, as noted in this essay: what is the additional influence of populism over nationalism in a state's reticence to cooperate because of delegation concerns? And where does partisanship lie in this mix?

In terms of general issues of public opinion and international organizations, an already-noted challenge is separating legitimacy-based process concerns (e.g., IOs are not democratic) from sovereignty cost concerns (e.g., IOs restrict policy discretion) and delegation-related outcome-oriented concerns (e.g., IOs enact policies not in line with a state's preferences). Do populists abandon their concerns over supposedly anti-democratic institutions if they get what they want in a bargain?

Second, the messenger likely matters. Although I have argued that public attitudes are important in the formulation of policy, it is the case that most voters are lowinformation in the realm of international cooperation. Thus, we return to the question of whether the public is leading or led. And if they are led, by whom? Could a populist leader convince followers to engage in international cooperation?

Anecdotally, the COVID-19 crisis gives us some evidence. In particular, the 2020 Trump administration turn against the WHO clearly hurt that organization's popularity in the United States. Guisinger and Saunders' study found wide support for and minimal polarization over the WHO prior to the COVID-19 crisis. ${ }^{103}$ This suggests either a significant gap between elite and public views of governance institutions or that the public was moved based on the Trump administration's criticism of that organization.

Empirical work is emerging on elite-mass opinion linkages on international issues. Gabel and Scheve investigate different methodologies of untangling the causal effect of elite messaging on European integration. ${ }^{104}$ More recently, Strezhnev, Simmons, and Kim examine how elite cues influence public perceptions of international law and its support for policy. ${ }^{105}$ Interestingly, they find that a co-partisan endorsement influences perceptions of the applicability of law, but not perceptions of policy. De Vries, Hobolt, and Walter make an excellent attempt to integrate the various factors of elite-

102. See Milner and Tingley 2013 for a related argument concerning control and multilateralism.

103. Guisinger and Saunders 2017. Previous surveys also found the WHO to have fairly widespread support: the Chicago Council Foreign Relations survey found 80\% of Americans supported strengthening the WHO in the previous decade. See Page and Bouton 2006, 155-6.

104. Gabel and Scheve 2007.

105. Strezhnev, Simmons, and Kim 2019. 
framing, regime characteristics, and politicization by generalizing these factors from European integration efforts to international cooperation. ${ }^{106}$

But while leader framing is certainly important, leaders do not engage in framing in a vacuum. What is the role, for example, of compliance constituencies ${ }^{107}$ or interest groups $^{108}$ in reshaping public opinion? Is it important that the compliance constituencies operate only within the domestic sphere or can international non-governmental organizations move opinion? ${ }^{109}$

Moreover, some scholars have noted that there appear to be gaps in opinion between elite and the public, with the public often holding global institutions in higher regard than elites assume. ${ }^{110}$ What has led to this disjuncture? Is public opinion on issues such as international law or global cooperation so fickle that it is hard to pin down? Is it possible that elites have shifted their views and behavior, but the mass public has not?

Finally, I agree with Guisinger and Saunders that much of the work on public attitudes across issue areas remains "unintegrated." 111 For example, there are differences in how scholars often approach attitudes towards international courts (legitimacy), international law (information/endorsement), and climate governance (regime design). These different theoretical starting points have led to different paths in research design, especially in experimental settings. There has been little effort to reconcile these theoretical and methodological differences. Scholarship on public opinion and cooperation has developed clearer pictures of trees, but does this scholarship tell us much about the contours of the forest?

The COVID-19 pandemic has raised myriad questions about international cooperation. I have argued that understanding the mechanisms by which populism influences international cooperation is an important avenue of research for this topic. Examining populist ideology sheds light on some of the difficulties in disentangling the various individual-level ideologies and attitudes that hang together around international cooperation. This research, while certainly challenging, will help us to better understand the nature of the relationship between domestic politics and international cooperation.

\section{References}

Aldrich, John H., John L. Sullivan, and Eugene Borgida. 1989. Foreign Affairs and Issue Voting: Do Presidential Candidates "Waltz Before a Blind Audience"? American Political Science Review 83 (1): 123-41.

Almond, Gabriel A. 1950. The American People and Foreign Policy. Brace and Co.

106. de Vries, Hobolt and Walter forthcoming.

107. Dai 2005; Simmons 2009.

108. Dür 2019.

109. Kreps and Wallace 2016.

110. See esp. Page and Bouton 2006.

111. Guisinger and Saunders 2017, 425. 
Baum, Matt A. 2002. The Constituent Foundations of the Rally-round-the-flag Phenomenon. International Studies Quarterly 46 (2):263-98.

Baum, Matt A. and Philip B. Potter. 2008. The Relationships Between Mass Media, Public Opinion, and Foreign Policy: Toward a Theoretical Synthesis. Annual Review of Political Science 11:39-65.

Bechtel, Michael M. and Kenneth F. Scheve. 2013. Mass Support for Global Climate Agreements Depends on Institutional Design. Proceedings of the National Academy of Sciences 110 (34):13763-8.

Bennett, W. Lance. 1990. Toward a Theory of Press-state Relations in the United States. Journal of Communication 40 (2):103-27.

Berinsky, Adam J. 2009. In Time of War: Understanding American Public Opinion from World War II to Iraq. University of Chicago Press.

Buchanan, Allen and Robert O. Keohane. 2006. The Legitimacy of Global Governance Institutions. Ethics and International Affairs 20 (4):405-37.

Busby, Joshua W. and Jonathan Monten. 2012. Republican Elites and Foreign Policy Attitudes. Political Science Quarterly 127 (1):105-42.

Chapman, Terrance L. 2009. Audience Beliefs and International Organization Legitimacy. International Organization 63 (4):733-64.

Chaudoin, Stephen. 2014. Promises or Policies? An Experimental Analysis of International Agreements and Audience Reactions. International Organization 68 (1):235-56.

Chilton, Adam S. 2014. The Influence of International Human Rights Agreements on Public Opinion: An Experimental Study. Chicago Journal of International Law 15:110-37.

Chilton, Adam S. 2015. The Laws of War and Public Opinion: An Experimental Study. Journal of Institutional and Theoretical Economics 171 (1):181-201.

Chilton, Adam S. and Mila Versteeg. 2016. International Law, Constitutional Law, and Public Support for Torture. Research \& Politics 3 (1):1-9.

Chittick, William O., Keith R. Billingsley, and Rick Travis. 1995. A Three-dimensional Model of American Foreign Policy Beliefs. International Studies Quarterly 39 (3):313-31.

Colantone, Italo and Piero Stanig. 2018. The Trade Origins of Economic Nationalism: Import Competition and Voting Behavior in Western Europe. American Journal of Political Science 62 (4): 936-53.

Converse, Philip E. 1964. The Nature of Belief Systems in Mass Publics (1964). In Ideology and its Discontents, edited by David E. Apter. The Free Press of Glencoe.

Copelovitch, Mark and Jon C.W. Pevehouse, 2019. International Organizations in a New Era of Populist Nationalism. The Review of International Organizations 14 (2):169-86.

Dahl, Robert A. 1999. Can International Organizations be Democratic? A Skeptic's View. In The Cosmopolitanism Reader, edited by Garrett Wallace Brown and David Held, 19-36. Polity Press.

Dai, Xinyuan. 2005. Why Comply? The Domestic Constituency Mechanism. International Organization 59 (2):363-98.

De Vries, Catherine E. 2018. Euroscepticism and the Future of European Integration. Oxford University Press.

De Vries, Catherine E., Sara Hobolt, and Stefanie Walter. Forthcoming. Politicizing International Cooperation: the Mass Public, Political Entrepreneurs and Political Opportunity Structures. International Organization.

Dellmuth, Lisa M., Jan Aart Scholte, and Jonas Tallberg. 2019. Institutional Sources of Legitimacy for International Organisations: Beyond Procedure Versus Performance. Review of International Studies 45 (4):627-46.

Diamond, Larry. 2008. The Democratic Rollback: The Resurgence of the Predatory State. Foreign Affairs 87 (2):36-48.

Drezner, Daniel. 2020. The Song Remains the Same: International Relations After COVID-19. International Organization 74 (S1). <https://doi.org/10.1017/S0020818320000351>.

Dür, Andreas. 2019. How Interest Groups Influence Public Opinion: Arguments Matter More Than the Sources. European Journal of Political Research 58 (2):514-35.

Fang, Songying. 2008. The Informational Role of International Institutions and Domestic Politics. American Journal of Political Science 52 (2):304-21. 
Findley, Michael G., Daniel L. Nielson, and Jason C. Sharman. 2013. Using Field Experiments in International Relations: A Randomized Study of Anonymous Incorporation. International Organization 67 (4):657-93.

Flockhart, Trine, ed., 2005. Socializing Democratic Norms: The Role of International Organizations for the Construction of Europe. Springer.

Gabel, Matthew and Kenneth Scheve. 2007. Estimating the Effect of Elite Communications on Public Opinion Using Instrumental Variables. American Journal of Political Science 51 (4):1013-28.

Glenn, Caileigh, and Jon C.W. Pevehouse. 2019. Democratic Backsliding and International Organizations. Paper presented at the 2019 Annual Meeting of the American Political Science Association, Washington D.C.

Gourevitch, Peter. 1978. The Second Image Reversed: the International Sources of Domestic Politics. International Organization 32 (4):881-912.

Grieco, Joseph M., Christopher Gelpi, Jason Reifler, and Peter D. Feaver. 2011. Let's Get a Second Opinion: International Institutions and American Public Support for War. International Studies Quarterly 55 (2):563-83.

Guisinger, Alexandra and Elizabeth N. Saunders. 2017. Mapping the Boundaries of Elite Cues: How Elites Shape Mass Opinion Across International Issues. International Studies Quarterly 61 (2):425-41.

Grossman, Gene M. and Elhanan Helpman. 2002. Interest Groups and Trade Policy. Princeton University Press.

Haas, Peter M. 1992. Introduction: Epistemic Communities and International Policy Coordination. International Organization 46(1):1-35.

Hafner-Burton, Emilie M. 2008. Sticks and Stones: Naming and Shaming the Human Rights Enforcement Problem. International Organization 62 (4):689-716.

Hafner-Burton, Emilie M., Edward D. Mansfield, and Jon C.W. Pevehouse. 2015. Human Rights Institutions, Sovereignty Costs and Democratization. British Journal of Political Science 45 (1):1-27.

Hahm, Hyeonho, Thomas König, Moritz Osnabruegge, and Elena Frech. 2019. Who Settles Disputes? Treaty Design and Trade Attitudes Toward the Transatlantic Trade and Investment Partnership (TTIP). International Organization 73 (4):881-900.

Helfer, Laurence R. 2020. Populism and International Human Rights Institutions: A Survival Guide. In Human Rights in a Time of Populism: Challenges and Responses, edited by Gerald L. Neuman, 218-49. Cambridge University Press.

Hiscox, Michael J. 2006. Through a Glass and Darkly: Attitudes Toward International Trade and the Curious Effects of Issue Framing. International Organization 60 (3):755-80.

Hobolt, Sara B. 2016. The Brexit Vote: a Divided Nation, a Divided Continent. Journal of European Public Policy 23 (9):1259-77.

Holsti, Ole. 1992. Public Opinion and Foreign Policy: Challenges to the Almond-Lippmann Consensus. International Studies Quarterly 36 (4):439-66.

Hooghe, Lisbett and Gary Marks. 2007. Sources of Euroscepticism. Acta Politica 42 (2-3):119-27.

Hook, Steven W. 2003. Domestic Obstacles to International Affairs: The State Department Under Fire at Home. PS: Political Science \& Politics 36 (1):23-29.

Howell, William G. and Jon C. Pevehouse. 2007. While Dangers Gather: Congressional Checks on Presidential War Powers. Princeton University Press.

Johns, Robert and Graeme A.M. Davies. 2014. Coalitions of the Willing? International Backing and British Public Support for Military Action. Journal of Peace Research 51 (6):767-81.

Johnson, Robert H. 1983. The New Populism and the Old: Demands for a New International Economic Order and American Agrarian Protest. International Organization 37 (1):41-72.

Johnson, Tana. 2020. Ordinary Patterns in an Extraordinary Crisis: How International Relations Makes Sense of the COVID-19 Pandemic. International Organization 74 (S1). <https://doi.org/10.1017/ S0020818320000430>.

Keck, Margaret E. and Kathryn Sikkink. 1998. Activists Beyond Borders: Advocacy Networks in International Politics. Cornell University Press. 
Keohane, Robert O. 1984. After Hegemony: Cooperation and Discord in the World Economy. Princeton University Press.

Kreps, Sara E. and Geoffrey P. Wallace. 2016. International Law, Military Effectiveness, and Public Support for Drone Strikes. Journal of Peace Research 53 (6):830-44.

Linsker, Drew. 2020. COVID-19 and the Challenge of Populism. Forbes. 2 April. Available at $<$ https:// www.forbes.com/sites/riskmap/2020/04/02/covid-19-and-the-failure-of-populism/?sh=495509e84f99>.

Madsen, Mikael, Juan A. Mayoral, Anton Strezhnev, and Erik Voeten. 2020. Sovereignty, Substance, and Public Support for European Courts. Available at <https://papers.ssrn.com/sol3/papers.cfm? abstract_id=3681988>.

Mansfield, Edward D., Helen V. Milner, and Jon C. Pevehouse. 2007. Vetoing Co-operation: The Impact of Veto Players on Preferential Trading Arrangements. British Journal of Political Science 37 (3): 403-32.

Mattes, Michaela, \& Mariana Rodríguez. 2014. Autocracies and International Cooperation. International Studies Quarterly 58 (3):527-38.

Milner, Helen V. 1997. Interests, Institutions, and Information: Domestic Politics and International Relations. Princeton University Press.

Milner, Helen V. and Dustin Tingley. 2013. The Choice for Multilateralism: Foreign Aid and American Foreign Policy. The Review of International Organizations 8 (3):313-41.

Moravcsik, Andrew. 2000. The Origins of Human Rights Regimes: Democratic Delegation in Postwar Europe. International Organization 54 (2):217-52.

Morse, Julia C. and Robert O. Keohane. 2014. Contested Multilateralism. The Review of International Organizations 9 (4):385-412.

Mudde, Cas. 2014. Fighting the System? Populist Radical Right Parties and Party System Change. Party Politics 20 (2):217-26.

Mudde, Cas and Cristobal Kaltwasser. 2013. Exclusionary vs. Inclusionary Populism: Comparing Contemporary Europe and Latin America. Government and Opposition 48 (2):147-74.

Mutz, Diana C., 2018. Status Threat, Not Economic Hardship, Explains the 2016 Presidential Vote. Proceedings of the National Academy of Sciences 115 (19):E4330-39.

Myrick, Rachel. 2019. Do External Threats Unite or Divide? Security Threats, Rivalries, and Polarization in American Foreign Policy. Paper presented at the 2019 Annual Meeting of the American Political Science Association, Washington D.C.

Nai, Alessandro and Ferran Martinez i Coma. 2019. The Personality of Populists: Provocateurs, Charismatic Leaders, or Drunken Dinner Guests? West European Politics 42 (7):1337-67.

Nincic, Miroslav. 1992. A Sensible Public: New Perspectives on Popular Opinion and Foreign Policy. Journal of Conflict Resolution 36 (4):772-89.

O'Brien, Robert, Anne Marie Goetz, Jan Aart Scholte, and Marc Williams. 2000. Contesting Global Governance: Multilateral Institutions and Global Social Movements. Cambridge University Press.

Page, Benjamin I. and Marshall M. Bouton. 2006. The Foreign Policy Disconnect: What Americans Want from our Leaders but Don't Get. University of Chicago Press.

Pelc, Kryzstof J. 2013. Googling the WTO: What Search-engine Data Tell us About the Political Economy of Institutions. International Organization 67 (3):629-55.

Pevehouse, Jon C. 2002. Democracy From the Outside-In? International Organizations and Democratization. International Organization 56 (3):515-49.

Powell, Robert. 1991. Absolute and Relative Gains in International Relations Theory. American Political Science Review 85 (4):1303-1320.

Powers, Kathleen E. 2020. Nationalism, Social Identity Content, and Foreign Policy Attitudes. Working Paper. Dartmouth University.

Powlick, Philip J. and Andrew Z. Katz. 1998. Defining the American Public Opinion/Foreign Policy Nexus. Mershon International Studies Review 42 (Supplement 1):29-61.

Putnam, Tonya L. and Jacob N. Shapiro. 2017. International Law and Voter Preferences: the Case of Foreign Human Rights Violations. Human Rights Review 18 (3):243-62. 
Rabkin, Jeremy A. 2005. Law Without Nations? Why Constitutional Government Requires Sovereign States. Princeton University Press.

Rachman, Gideon. 2020. Coronavirus Could Kill off Populism. Financial Times. 29 June. Available at <https://www.ft.com/content/3bcf2b5e-e5f1-48e4-bb15-cd29615a9198>.

Rosendorff, B. Peter and Helen V. Milner. 2001. The Optimal Design of International Trade Institutions: Uncertainty and Escape. International Organization 55(4):829-57.

Rubenfeld, Jed. 2004. Unilateralism and Constitutionalism. New York University Law Review 79 (6):19712028.

Rudra, Nita. 2002. Globalization and the Decline of the Welfare State in Less-developed Countries. International Organization 56 (2):411-45.

Schmidtke, Henning. 2019. Elite Legitimation and Delegitimation of International Organizations in the Media: Patterns and Explanations. The Review of International Organizations 14 (4):633-659.

Simmons, Beth A. 2009. Mobilizing for Human Rights: International Law in Domestic Politics. Cambridge University Press.

Söderbaum, Fredrick, Kilian Spandler, and Agnese Pacciardi. 2021. Contestations of the Liberal International Order: A Populist Script of Regional Cooperation. Cambridge Elements in International Relations. Cambridge University Press.

Soroka, Stuart N. 2003. Media, Public Opinion, and Foreign Policy. Harvard International Journal of Press/Politics 8 (1):27-48.

Snyder, Jack. 1991. Myths of Empire: Domestic Politics and International Ambition. Cornell University Press.

Strezhnev, Anton, Beth A. Simmons, and Matthew D. Kim. 2019. Rulers or Rules? International Law, Elite Cues and Public Opinion. European Journal of International Law 30 (4):1281-302.

Tallberg, Jonas, Karin Bäckstrand, and Jan Aart Scholte. 2018. Introduction: Legitimacy in Global Governance. In Legitimacy in Global Governance: Sources, Processes, and Consequences, edited by Jonas Tallberg, Karin Bäckstrand, and Jan Aart Scholte, 3-19. Oxford University Press.

Tallberg, Jonas and Michael Zürn. 2019. The Legitimacy and Legitimation of International Organizations: Introduction and Framework. Review of International Organizations 14:581-606.

Tingley, Dustin and Michael Tomz. 2014. Conditional Cooperation and Climate Change. Comparative Political Studies 47 (3):344-68.

Thompson, Alexander. 2006. Coercion Through IOs: The Security Council and the Logic of Information Transmission. International Organization 60 (1):1-34.

Tomz, Michael, Jessica L.P. Weeks, and Keren Yarhi-Milo. 2020. Public Opinion and Decisions About Military Force in Democracies. International Organization 74 (1):119-43.

Verbeek, Bertjan and Andrej S. Zaslove. 2017. Populism and Foreign Policy. In The Oxford Handbook of Populism, edited by Cristobal R. Kaltwasser, Paul A. Taggart, and Paulina O. Espejo, 384-405. Oxford University Press.

Voeten, Erik. 2013. Public Opinion and the Legitimacy of International Courts. Theoretical Inquiries in Law 14 (2):411-36.

Wallace, Geoffrey P.R. 2013. International Law and Public Attitudes Toward Torture: An Experimental Study. International Organization 67 (1):105-40.

Zaller, John R. 1992. The Nature and Origins of Mass Opinion. Cambridge University Press.

Zaslav, Mark R. 1998. Shame-related States of Mind in Psychotherapy. The Journal of Psychotherapy Practice and Research 7 (2):154-66.

\section{Authors}

Jon C.W. Pevehouse is the Vilas Distinguished Professor of Political Science and Public Affairs at the University of Wisconsin-Madison. He can be reached at pevehouse@polisci.wisc.edu. 


\section{Acknowledgements}

For helpful feedback and suggestions I would like to thank Michael Barnett, Kim Yi Dionne, Tanisha Fazal, Martha Finnemore, Michael Horowitz, Tana Johnson, Michael Kenwick, Elana Matthews, Kenneth Scheve, Kenneth Schultz, Beth Simmons, David Stasavage, Erik Voeten, and Jessica Weeks. Thanks also to the Editorial Team of International Organization and to Perry World House for organizing the virtual workshop for which this paper was written.

\section{Key Words}

populism; international cooperation; public opinion; legitimacy; delegation 